Publiser
Graduate Program Universitas Galuh
Master of Manajemen Studies Program

\title{
IMPLEMENTASI PERMENDAGRI NOMOR 17 TAHUN 2007 DALAM RANGKA EFISIENSI PENATAUSAHAAN BARANG MILIK DAERAH
}

\author{
Devi Indra Nursasona \\ Program Studi Magister Manajemen, Program Pascasarjana Universitas Galuh Ciamis \\ e-mail : indradevi@gmail.com
}

\begin{abstract}
Article History :
Recieved 12 April 2017

Recieved in revished form

21 April 2017

Acepted 5 May 2017

Available offline 10 May 2017

Available online 10 May 2017
\end{abstract}

Language Transcript :

Indonesia

Key Words :

Implmentasi

Efisiensi

Penatausahaan

Barang Milik Daerah

\begin{abstract}
Penelitian ini bertujuan untuk mendeskripsikan tentang implementasi Permendagri Nomor 17 Tahun 2007 tentang Pedoman Teknis Pengelolaan Barang Milik Daerah dalam rangka efisiensi penatausahaan barang milik daerah pada Dinas Pendapatan Pengelolaan Keuangan dan Aset Daerah Kabupaten Ciamis.Penelitian ini menggunakan pendekatan kualitatif, adapun metode yang digunakan adalah deskriptif kualitatif. Berdasarkan hasil temuan dilapangan ditemukan sebagai berikut implementasi Permendagri Nomor 17 Tahun 2007 tentang Pedoman Teknis Pengelolaan Barang Milik Daerah telah dilaksanakan sesuai ketentuan di Kabupaten Ciamis namun belum mencapai derajat kesesuaian terhadap Permendagri Nomor 17 Tahun 2007. Disisi lain efisiensi penatausahaan barang milik daerah dari segi keandalan, sistem dan prosedur, fleksibilitas serta hasil yang dicapai telah mampu mewujudkan hasil yang baik dalam mengimplementasikan Permendagri Nomor 17 tahun 2007 tentang Pedoman Teknis Pengelolaan Barang Milik Daerah di Kabupaten Ciamis. Dalam meningkatkan efisiensi penatausahaan barang milik daerah, telah dilakukan upaya-upaya kegiatan peningkatan kompetensi sumber daya aparatur pengelola barang milik daerah melalui bimbingan teknis pengelolaan barang daerah bagi para pengurus barang, penyediaan sarana dan prasarana kerja bagi pengelolaan aset daerah, pengembangan dan peningkatan aplikasi sistem informasi manajemen barang daerah. Pelaksanaan rekonsiliasi data aset tetap pada setiap awal bulan secara konsisten dan terus menerus untuk menginternalisasikan kerangka disiplin pada masing-masing tanggungjawab individu.
\end{abstract}

\section{PENDAHULUAN}

Pengelolaan barang milik daerah merupakan bagian dari pengelolaan keuangan daerah yang dilaksanakan secara terpisah dari pengelolaan barang milik negara. Barang milik daerah merupakan salah satu unsur penting dalam rangka penyelenggaraan pemerintahan dan pelayanan masyarakat yang harus dikelola dengan baik dan benar. Siklus pengelolaan barang milik daerah meliputi:
Perancanaan kebutuhan dan penganggaran,

(2) Pengadaan, (3) Penerimaan, penyimpanan dan penyaluran, Penggunaan, (5) Penatausahaan (6) Pemanfaatan (7) Pengamanan dan pemeliharaan (8) Penilaian Penghapusan (10) Pemindahtanganan (11) Pembinaan, pengawasan dan pengendalian (12) Pembiayaan dan (13) Tuntutan ganti rugi. 
Salah satu siklus yang penting dalam pengelolaan barang milik daerah adalah penatausahaan barang milik daerah. Proses inventarisasi, baik berupa pendataan, pencatatan, dan pelaporan hasil pendataan barang milik daerah merupakan bagian dari penatausahaan. Hasil dari proses pembukuan dan inventarisasi diperlukan dalam melaksanakan proses pelaporan barang milik daerah yang dilakukan oleh kuasa pengguna barang, pengguna barang, dan pengelola barang. Hasil penatausahaan barang milik daerah digunakan dalam rangka: penyusunan neraca pemerintah daerah setiap tahun, perencanaan kebutuhan pengadaan dan pemeliharaan barang milik daerah setiap tahun untuk digunakan sebagai bahan penyusunan rencana anggaran dan pengamanan administratif terhadap barang milik daerah.

Dibuatnya Peraturan Menteri Dalam Negeri Nomor 17 Tahun 2007 tentang Pedoman Teknis Pengelolaan Barang Milik Daerah bertujuan sebagai pedoman pelaksanaan bagi pejabat/aparat pengelola barang milik daerah secara menyeluruh sehingga dapat dipakai sebagai acuan oleh semua pihak dalam rangka melaksanakan tertib administrasi pengelolaan barang milik daerah secara efektiv dan efisien yang mencakup data yang terdiri dari jenis, jumlah, nilai dan kondisi barang milik daerah.

Dalam penyusunan laporan barang milik daerah, untuk memudahkan konsolidasi data barang milik daerah dari masingmasing Satuan Kerja Perangkat Daerah (SKPD), maka dibutuhkan suatu sistem manajemen pengelolaan barang milik daerah. Pemerintah Daerah Kabupaten Ciamis dalam pengelolaan barang milik daerah dilaksanakan dengan menggunakan aplikasi Sistem Informasi Manajemen Daerah Barang Milik Daerah (SIMDABMD) dengan tujuan agar dalam pengelolaan barang milik daerah terdapat keseragaman baik dalam proses pencatatan, penginputan data maupun pelaporan barang milik daerah.

Dari beberapa penelitian terdahulu yang menyangkut pengelolaan barang milik daerah, hasilnya sangat bervariasi, yaitu sebagai berikut: (1) Sepuluh tahapan pengelolaan BMD telah dilaksanakan dengan baik, (2) Pengelolaan BMD memberikan dampak yang signifikan terhadap pengamanan aset daerah, dan (3) Manajemen aset daerah menurut Permendagri No. 17 Tahun 2007 telah dilaksanakan sesuai ketentuan.

\section{METODOLOGI}

Dalam penelitian ini, pendekatan penelitian yang digunakan adalah pendekatan kualitatif. Pendekatan kualitatif menekankan pada makna dan pemahaman dari dalam, penalaran, definisi suatu situasi tertentu, lebih banyak meneliti hal-hal yang berhubungan dengan kehidupan sehari-hari. Pendekatan kualitatif, lebih lanjut, mementingkan pada proses dibandi ngkan dengan hasil akhir. Adapun metode yang digunakan dalam penelitian ini adalah metode deskriptif kualitatif. Metode kualitatif digunakan untuk mendapatkan data yang mendalam, suatu data yang mengandung makna. Makna adalah data yang sebenarnya, data yang pasti yang merupakan suatu nilai di balik data yang tampak. Oleh karena itu dalam penelitian kualitatif tidak menekankan pada generalisasi, tetapi lebih menekankan pada makna (Sugiyono, 2014:22).

Penelitian dilaksanakan dari mulai bulan Februari 2016 sampai dengan April 2016 di Dinas Pendapatan Pengelolaan Keuangan dan Aset Daerah Kabupaten Ciamis. Keabsahan dan keajegan penelitian ini diuji dengan cara melakukan proses triangulasi secara terus menerus sejak data dideskripsikan, dianalisis, ditafsirkan hingga data tersebut disimpulkan sebagai 
upaya menjawab masalah penelitian. Menurut Sugiyono (2014:31) hasil akhir dari penelitian kualitatif, bukan sekedar menghasilkan data atau informasi yang sulit dicari melalui metode kuantitatif, tetapi juga harus mampu menghasilkan informasiinformasi yang bermakna, bahkan hipotesis atau ilmu baru yang dapat digunakan untuk membantu mengatasi masalah dan meningkatkan taraf hidup manusia.

Desain penelitian yang dirancang oeh peneliti adalah penelitian kasus dan penelitian lapangan dengan tahapan; (a). Tahap Perencanaan, (b). Tahap Pelaksanaan Penelitian yang meliputi pengumpulan data melalui wawancara, observasi dan studi dokumentasi serta pengidentifikasian data, (c). Tahap Akhir Penelitian yang terdiri dari menyajikan data dalam bentuk derskripsi dan menganalisa data sesuai dengan tujuan yang ingin dicapai.

\section{HASIL DAN PEMBAHASAN}

\subsection{Hasil}

a. Implementasi Permendagri Nomor 17 Tahun 2007 tentang Pedoman Teknis Pengelolaan Barang Milik Daerah

Peraturan Menteri Dalam Negeri (Permendagri) No. 17 Tahun 2007 mengatur tentang pengelolaan barang milik daerah yang meliputi serangkaian proses dari mulai perencanaan kebutuhan dan penganggaran, pengadaan penerimaan, penyimpanan dan penyaluran, penggunaan, penatausahaan, pemanfaatan, pengamanan dan pemeliharaan, penilaian, penghapusan, pemindahtanganan, pembinaan, pengawasan dan pengendalian, pembiayaan dan Tuntutan Ganti Rugi (TGR). Berdasarkan hasil penelitian dilapangan, pengelolaan barang milik daerah telah dilaksanakan sesuai ketentuan, akan tetapi belum mencapai derajat kesesuaian terhadap Peraturan Menteri Dalam Negeri
(Permendagri) No. 17 Tahun 2007, artinya masih terdapat beberapa aspek yang belum dilaksanakan antara lain: (1) Laporan hasil pemeliharaan barang oleh Pengguna Barang kepada Pengelola (Sekda) belum dibuat, (2) Laporan hasil pengadaan barang oleh Pengguna Barang kepada Pengelola (Sekda) belum dibuat, (3) Surat Perintah Pengeluaran Barang (SPPB) sebagai dasar penyaluran barang oleh pengurus barang belum dilaksanakan, dan (4) Dalam hal pemindahtanganan, laporan hasil penjualan, tukar menukar dan penyertaan modal yang harus disampaikan kepada Menteri Dalam Negeri belum dilaksanakan.

\section{b. $\quad$ Efisiensi Penatausahaan Barang Milik Daerah}

Dalam penatausahaan barang milik daerah, ketepatan dan keakuratan data sangat diperlukan. Sedangkan kecepatan dalam menginput dan mengolah data barang daerah menjadi bagian yang tidak dapat dipisahkan dari kegiatan penatausahaan barang milik daerah. Artinya bahwa penatausahaan barang milik daerah harus dilakukan secara efisien, sebagaimana di kemukakan oleh Rahardjo Adisasmita (2011) pengertian Efisiensi "Merupakan komponen-komponen input yang digunakan seperti waktu, tenaga dan biaya dapat dihitung penggunaannya dan tidak berdampak pada pemborosan atau pengeluaran yang tidak berarti”. Penatausahaan barang milik daerah sesuai Permendagri Nomor 17 Tahun 2007 tentang Pedoman Teknis Pengelolaan Barang Milik Daerah dilakukan dalam 3 (tiga) kegiatan yang meliputi kegiatan pembukuan, inventarisasi dan pelaporan. Penatausahaan barang milik daerah dapat dilaksanakan secara efektive dan efisien dengan melihat faktor penentu tercapainya tujuan yang diinginkan dengan memfokuskan pada aspek: Keandalan, Sistem dan Prosedur, Fleksibilitas dan Hasil yang Dicapai.

(1) Keandalan

Kata keandalan dapat diartikan dengan terpercaya dalam memenuhi suatu kebutuhan. Kebutuhan dalam hal ini adalah 
tersajinya data barang milik daerah sesuai dengan yang diharapkan, salah satunya adalah ketepatan waktu dalam penyampaian laporan barang milik daerah.

Penyampaian Laporan Keuangan Pemerintah Daerah (LKPD) telah dapat disampaikan tepat waktu sesuai peraturan perundangan-undangan yaitu 3 (tiga) bulan setelah tahun anggaran berakhir yaitu bulan Maret. Artinya bahwa efisiensi penatausahaan barang milik daerah yang meliputi kegiatan pembukuan, inventarisasi dan pelaporan melalui penggunaan aplikasi Sistem Informasi Manajemen Barang Daerah dapat memenuhi kebutuhan pemerintah daerah dalam penyusunan laporan barang milik daerah sesuai Permendagri Nomor 17 Tahun 2007.

Sistem adalah sekumpulan dari elemenelemen yang berinteraksi untuk mencapai tujuan tertentu. Sedangkan prosedur merupakan serangkaian aksi yang spesifik, tindakan atau operasi yang harus dijalankan atau dieksekusi dengan cara yang baku (sama) agar selalu memperoleh hasil yang sama dari keadaan yang sama. Hal ini dapat diindikasikan sebagai rangkaian aktivitas atau perhitungan-perhitungan yang dijalankan melalui serangkaian pekerjaan yang menghasilkan suatu tujuan yang diinginkan.

Dalam rangka efisiensi penatausahaan barang milik daerah, sistem dan prosedur yang dijalankan melalui proses inventarisasi, pembukuan dan pelaporan dengan menggunakan aplikasi sistem informasi barang milik daerah dapat menghasilkan laporan yang diinginkan. Para pengurus barang maupun operator SIMDA-BMD pada setiap SKPD sebagai elemen dalam rangkaian penatausahaan barang milik daerah selalu berinteraksi dan mengambil peranan yang sangat penting dalam proses penginputan data secara berjenjang maupun periodik dengan operator SIMDA-BMD pada Dinas PPKAD http://jurnal.unigal.ac.id/index.php/managementreview

selaku pembantu pengelola yang mempunyai tugas mengkonsolidasikan data BMD meliputi KIB A sampai dengan KIB F dari seluruh SKPD. Selanjutnya prosedur yang dijalankan dalam rangka efisiensi penatausahaan barang milik daerah telah mampu menghasilkan data yang dibutuhkan. Prosedur yang diterapkan adalah melalui kegiatan rekonsiliasi data aset yang harus dilakukan setiap awal bulan untuk mencatat realisasi data barang yang diperoleh baik dari hasil pengadaan belanja modal, penghapusan maupun penambahan dan pengurangan jumlah aset. Efisiensi dari segi waktu, proses penatausahann barang milik daerah telah mampu menyajikan data yang dibutuhkan, hanya dengan sekali penginputan maka pelaporan data secara berjenjang dari mulai kuasa pengguna, kemudian ke pengguna, lalu ke pengelola melalui pembantu pengelola data tersebut dikonsolidasikan untuk bahan penyusunan laporan barang milik daerah. Artinya sistem dan prosedur yang dilaksanakan untuk mengimplementasikan Permendagri Nomor 17 Tahun 2007 tentang Pedoman Teknis Pengelolaan Barang Milik Daerah telah mampu untuk mewujudkan secara efisien dalam rangka penatausahaan barang milik daerah.

(2) Fleksibilitas

Implementasi Permendagri Nomor 17 Tahun 2007 dari segi fleksiblitas telah mampu dilaksanakan secara efisien dalam rangka penatausahaan barang milik daerah. Artinya aplikasi sistem informasi penatausahaan barang milik daerah yang digunakan telah mampu menghadapi perubahan peraturan perundang-undangan yang terus berubah. Salah satunya adalah dengan diberlakukannya laporan keuangan berbasis akrual sesuai Peraturan Pemerintah Republik Indonesia Nomor 71 tahun 2010 tentang Standar Akuntansi Pemerintahan. Berdasarkan peraturan tersebut terkait neraca aset tetap harus menyajikan 
akumulasi penyusutan. Aplikasi sistem ini telah mampu mengakomodir kebutuhan tersebut sehingga laporan barang milik daerah dapat disusun sesuai ketentuan peraturan perundang-undangan yang berlaku.

\section{(3) Hasil yang Dicapai}

Efisiensi penatausahaan barang milik daerah, salah satunya dapat diketahui dari hasil yang dicapai. Artinya bahwa hasil yang dicapai dapat diwujudkan sesuai keinginan dan rencana yang telah ditetapkan sebelumnya. Dalam pengelolaan barang milik daerah target yang ingin dicapai adalah terciptanya administrasi pengelolaan dan penatausahaan barang milik daerah yang baik dan terlaksananya penyampaian laporan barang milik daerah secara tepat waktu serta datanya dapat disajikan secara akurat.

Penyampaian laporan barang milik daerah yang disampaikan berbarengan dengan penyampaian laporan keuangan pemerintah daerah, selama tiga tahun berturut-turut dari mulai Tahun 2013 sampai dengan 2015 dapat disampaikan tepat waktu yaitu setiap tanggal 31 Maret pada tahun anggaran berkenaan atau 3 (tiga) bulan setelah tahun anggaran berakhir.

Terkait hasil yang dicapai dalam rangka efisiensi penatausahaan barang milik daerah, dapat dilihat dari aspek nilai aset tetap pada neraca daerah yang harus disajikan. Nilai aset tetap pada neraca daerah, telah dapat disajikan sesuai dengan yang diharapkan. Rincian nilai aset tetap pada neraca akhir tahun yang terdiri dari: Nilai Tanah (KIB A), Peralatan dan Mesin (KIB B), Gedung dan Bangunan (KIB C), Jalan, Irigasi dan Jaringan (KIB D), Aset Tetap Lainnya (KIB E), Konstruksi Dalam Pengerjaan (KIB F) serta Akumulasi Penyusutan secara signifikan telah disusun dan dapat disajikan secara akurat serta sesuai dengan Standar Akuntansi Pememrintahan (SAP). http://jurnal.unigal.ac.id/index.php/managementreview

c. Upaya-upaya Untuk Meningkatkan Efisiensi Penatausahaan Barang Milik Daerah

Dalam melaksanakan penatausahaan barang milik daerah, seringkali dihadapkan pada kendala-kendala yang ada di lapangan. Apabila kendala-kendala tersebut tidak diatasi maka akan berpengaruh terhadap pencapaian tujuan yang telah ditetapkan yaitu terciptanya tertib administrasi pengelolaan dan penatausahaan barang milik daerah sesuai peraturan perundangundangan khususnya Permendagri Nomor 17 Tahun 2007. Kendala yang dihadapai dalam rangka pengelolaan barang milik daerah antara lain adalah sebagai berikut:

a) Kualitas Sumber Daya Manusia (SDM) aparatur pengelola barang masih perlu ditingkatkan.

Dalam penatausahaan barang milik daerah, keberadaan SDM baik sebagai pengurus barang maupun sebagai operator SIMDA-BMD komoetensinya masih perlu ditingkatkan. Kualitas SDM ini berkaitan dengan kemampuan dalam menguasai dan mengoperasikan aplikasi sistem informasi manajemen barang milik daerah (SIMDA-BMD). Sesuai dengan perkembangannya, peraturan mengenai tata kelola keuangan dan aset daerah terus mengalami perubahan kearah yang lebih baik. Sejalan dengan perubahan tersebut maka aplikasi sistem informasi manajemen pengelolaan barang daerah pun mengalami perubahan dan pengembangan. Hal ini menuntut para pengurus barang maupun operator untuk mampu menguasai dan beradaptasi terhadap perubahan tersebut. Untuk mengatasi hal tersebut, telah dilaksanakan upaya untuk meningkatkan kompetensi para pengurus barang melalui kegiatan bimbingan teknis pengelolaan barang 
milik daerah yang dilaksanakan secara konsisten dan terus menerus.

b) Keterbatasan sarana dan prasarana.

Dalam melaksanakan penatausahaan barang milik daerah, tidak mungkin dapat berjalan dengan baik apabila tidak didukung oleh sarana dan prasarana yang memadai. Sarana yang paling penting dalam hal penatausahaan barang milik daerah adalah Komputer ataupun Laptop. Karena setiap tahapan dalam proses penatausahaan barang milik daerah pada akhirnya harus dinputkan kedalam aplikasi sistem informasi manajemen barang daerah. Kendala yang sering muncul adalah terkait masalah kurangnya kapasitas atau kemampuan komputer atau laptop dalam memproses data sehingga tidak mampu memproses data secara cepat, bahkan mengalami kegagalan dalam memproses data yang akhirnya menghambat dalam proses penyusunan data, khususnya data aset tetap.

Untuk mengatasi hal tersebut, khusus untuk 7 (tujuh) kelurahan dan 26 (duapuluh enam) kecamatan yang ada di Kabupaten Ciamis telah diberikan bantuan sarana berupa Komputer PC beserta printernya untuk mendukung kegiatan penatausahaan keuangan dan aset daerah.

c) Sistem informasi manajemen aset tetap masih perlu ditingkatkan.

Dalam rangka meningkatkan kemampuan aplikasi sistem informasi manajemen pengelolaan barang milik daerah adalah dengan melakukan pengembangan dan pemeliharaan aplikasi sistem informasi manajamen pengelolaan barang milik daerah. Pegembangan ini dilakukan untuk menyediakan data base mengenai kondisi di daerah dari aspek aset daerah yang dapat digunakan untuk penilaian kinerja instansi pemerintah daerah. Menghasilkan informasi yang komprehensif, tepat dan akurat kepada manajemen pemerintah daerah. Informasi ini dapat digunakan sebagai bahan untuk mengambil keputusan serta mempersiapkan aparat daerah untuk mencapai tingkat penguasaan dan pendayagunaan teknologi informasi yang lebih baik.

Pengembangan sistem ini dilakukan sebagai upaya untuk mengantisipasi dan menjawab setiap perubahan kebijakan dalam hal penatausahaan keuangan dan aset daerah. Sebagai contoh dengan diberlakukannya Peraturan Pemerintah Republik Indonesia Nomor 71 Tahun 2010 tentang Standar Akuntansi Pemerintahan. Berdasarkan peraturan dimaksud pemerintah daerah harus menerapkan laporan keuangan berbasis akrual, yang mana dalam penyajian neraca aset tetap harus mencantumkan nilai akumulasi penyusutan. Maka aplikasi sistem informasi manajemen barang daerah juga terus dikembangkan untuk mengakomodir kebutuhan data dimaksud seperti yang diamanatkan dalam perubahan peraturan perundang-undangan tersebut.

\subsection{Pembahasan}

A. Implementasi Permendagri Nomor 17 Tahun 2007 tentang Pedoman Teknis Pengelolaan Barang Milik Daerah

Peraturan Menteri Dalam Negeri (Permendagri) No. 17 Tahun 2007 mengatur tentang pengelolaan barang milik daerah yang meliputi serangkaian proses dari mulai perencanaan kebutuhan dan penganggaran, pengadaan penerimaan, penyimpanan dan penyaluran, penggunaan, 
penatausahaan, pemanfaatan, pengamanan dan pemeliharaan, penilaian, penghapusan, pemindahtanganan, pembinaan, pengawasan dan pengendalian, pembiayaan dan Tuntutan Ganti Rugi (TGR).

Berdasarkan hasil penelitian dilapangan seluruh proses pengelolaan barang milik daerah sebagaimana diatur dalam Peraturan Menteri Dalam Negeri (Permendagri) No. 17 Tahun 2007 telah dilaksanakan sesuai ketentuan. Akan tetapi masih terdapat beberapa tahapan yang belum dilaksanakan, hal ini harus menjadi perhatian pemerintah daerah untuk dapat menindaklanjutinya mengingat Peraturan Menteri Dalam Negeri (Permendagri) No. 17 Tahun 2007 dijadikan sebagai pedoman dalam pengelolaan barang milik daerah sehingga akan tercipta tertib administrasi dalam hal pengelolaan dan penatausahaan aset daerah.

\section{B. Efisiensi Penatausahaan Barang Milik Daerah}

Dalam rangka efisiensi penatausahaan barang milik daerah sesuai Permendagri Nomor 17 Tahun 2007 tentang Pedoman Teknis Pengelolaan Barang Milik Daerah dilakukan dalam 3 (tiga) kegiatan yang meliputi kegiatan pembukuan, inventarisasi dan pelaporan.

Efisiensi Penatausahaan barang milik daerah dapat dilaksanakan dengan tujuan yaitu terciptanya tertib administrasi penatausahaan dan pengelolaan barang milik daerah yang difokuskan pada aspek: 1) Keandalan, 2) Sistem dan Prosedur,3) Fleksibilitas dan 4) Hasil yang Dicapai.

\section{1) Keandalan}

Dinas Pendapatan Pengelolaan Keuangan dan Aset Daerah telah mampu menyampaikan Laporan Keuangan Pemerintah Daerah (LKPD) secara tepat waktu sesuai peraturan perundanganundangan.

Dengan menggunakan aplikasi Sistem Informasi Manajemen Barang Daerah
(SIMDA-BMD) dapat dipercaya atau memiliki keandalan dalam memenuhi kebutuhan pemerintah daerah dalam penyusunan laporan barang milik daerah.

Dengan menggunaan aplikasi Sistem Informasi Manajemen Barang Daerah, penatausahaan barang milik daerah yang meliputi kegiatan pembukuan, inventarisasi dan pelaporan dapat memenuhi kebutuhan pemerintah daerah dalam penyusunan laporan barang milik daerah dapat dilaksanakan secara efisien.

\section{2) Sistem dan Prosedur}

Dalam rangka efisiensi penatausahaan barang milik daerah, sistem dan prosedur yang dijalankan melalui proses inventarisasi, pembukuan dan pelaporan dengan menggunakan aplikasi sistem informasi barang milik daerah dapat menghasilkan laporan yang diinginkan. Para pengurus barang maupun operator SIMDA-BMD pada setiap SKPD sebagai elemen dalam rangkaian penatausahaan barang milik daerah selalu berinteraksi dan mengambil peranan yang sangat penting dalam proses penginputan data secara berjenjang maupun periodik dengan operator SIMDA-BMD pada Dinas PPKAD selaku pembantu pengelola yang mempunyai tugas mengkonsolidasikan data BMD meliputi KIB A sampai dengan KIB F dari seluruh SKPD. Selanjutnya prosedur yang dijalankan dalam rangka efisiensi penatausahaan barang milik daerah telah mampu menghasilkan data yang dibutuhkan. Melalui kegiatan rekonsiliasi data aset yang dilakukan setiap awal bulan telah mampu mencatat semua realisasi data barang yang diperoleh baik dari hasil pengadaan belanja modal, penghapusan maupun penambahan dan pengurangan jumlah asset dari mulai tanggal 1 Januari sampai dengan 31 desember. Sehingga memudahkan dalam penyusunan laporan barang milik daerah pada akhir tahun. Efisiensi dari segi waktu, proses 
penatausahann barang milik daerah telah mampu menyajikan data yang dibutuhkan, hanya dengan sekali penginputan maka pelaporan data secara berjenjang dari mulai kuasa pengguna, kemudian ke pengguna, lalu ke pengelola melalui pembantu dapat digabungkan untuk bahan penyusunan laporan barang milik daerah. Artinya sistem dan prosedur yang dilaksanakan telah mampu untuk mewujudkan secara efisien dalam rangka penatausahaan barang milik daerah.

\section{3) Fleksibilitas}

Dari segi fleksiblitas telah mampu mewujudkan penatausahaan barang milik daerah secara efisien. Artinya aplikasi sistem informasi penatausahaan barang milik daerah yang digunakan telah mampu menghadapi perubahan peraturan perundang-undangan yang berubah. Salah satunya adalah dengan diberlakukannya laporan keuangan berbasis akrual sesuai Peraturan Pemerintah Republik Indonesia Nomor 71 tahun 2010 tentang Standar Akuntansi Pemerintahan. Berdasarkan peraturan tersebut terkait neraca aset tetap harus menyajikan akumulasi penyusutan. Aplikasi sistem ini telah mampu mengakomodir kebutuhan tersebut sehingga laporan barang milik daerah dapat disusun sesuai ketentuan peraturan perundangundangan yang berlaku, yaitu terkait mengenai akumulasi penyusutan yang harus disajikan dalam neraca laporan barang milik daerah telah dapat dipenuhi.

\section{4) Hasil yang Dicapai}

Efisiensi penatausahaan barang milik daerah, salah satunya dapat diketahui dari hasil yang dicapai. Dalam pengelolaan barang milik daerah target yang ingin dicapai adalah terciptanya administrasi pengelolaan dan penatausahaan barng milik daerah yang baik dan terlaksananya penyampaian laporan barang milik daerah secara tepat waktu serta datanya dapat disajikan secara akurat.
Penyusunan dan penyampaian Laporan Barang Milik Daerah (LBMD) Kabupaten Ciamis kepada pihak BPK-RI dapat dilaksanakan tepat waktu sesuai dengan target yang telah ditetapkan. Penyampaian laporan barang milik daerah yang disampaikan berbarengan dengan penyampaian laporan keuangan pemerintah daerah, selama tiga tahun berturut-turut dari mulai Tahun 2013 sampai dengan 2015 dapat disampaikan tepat waktu yaitu setiap tanggal 31 Maret pada tahun anggaran berkenaan atau 3 (tiga) bulan setelah tahun anggaran berakhir.

Terkait hasil yang dicapai dalam rangka efisiensi penatausahaan barang milik daerah, dapat dilihat dari aspek nilai aset tetap pada neraca daerah yang harus disajikan. Nilai aset tetap pada neraca daerah, berdasarkan data telah dapat disajikan sesuai dengan yang diharapkan seerta ketentuan yang berlaku.

\section{Upaya-upaya Untuk Meningkatkan Efisiensi Penatausahaan Barang Milik Daerah}

Dalam melaksanakan penatausahaan barang milik daerah, seringkali dihadapkan pada kendala-kendala yang ada di lapangan. Apabila kendala-kendala tersebut tidak diatasi maka akan berpengaruh terhadap pencapaian tujuan yang telah ditetapkan yaitu terciptanya tertib administrasi pengelolaan dan penatausahaan barang milik daerah sesuai peraturan perundangundangan khususnya Permendagri Nomor 17 Tahun 2007.

Adapun kendala-kendala yang dihadapi dalam pengelolaan barang milik daerah antara lain sebagai berikut: a) Kualitas Sumber Daya Manusia (SDM) aparatur pengelola barang masih perlu ditingkatkan, b) Keterbatasan sarana dan prasarana dan c) Sistem informasi manajemen aset tetap masih perlu ditingkatkan. 
Untuk mengatasi kendala-kendala tersebut, maka dilakukan upaya-upaya sebagai berikut:

1) Meningkatkan kualitas Sumber Daya Manusia (SDM) aparatur pengelola barang.

Dalam rangka meningkatkan kompetensi aparatur pengelola barang, bagi para pengurus barang maupun operator adalah melalui: a) Bimbingan teknis dalam hal penatausahaan dan pengelolaan barang milik daerah secara konsisten dan berkesinambungan,

Dilaksanakannya kegiatan rekonsiliasi dan koordinasi bagi seluru pengurus barang. Hal ini dilakukan untuk menjaga konsistensi data aset tetap.

2) Melengkapi sarana dan prasarana bagi kegiatan pengelolaan keuangan dan aset.

Untuk mengatasi kendala terkait keterbatasan sarana dan prasarana, yaitu dengan telah dialokasikannya anggaran untuk kegiatan pelayanan administrasi perkantoran dan kegiatan peningkatan sarana dan prasarana aparatur. Pemberian bantuan perangkat komputer dan printer bagi 7 (Tujuh) Kelurahan dan 26 (Dua puluh enam) Kecamatan, penyediaan ruangan yang dilengkapi server serta printer bagi pelaksanaan kegiatan rekonsiliasi aset tetap untuk seluruh SKPD.

3) Meningkatkan dan mengembangkan sistem informasi manajemen aset tetap.

Upaya yang dilakukan dalam rangka meningkatkan kemampuan aplikasi sistem informasi manajemen pengelolaan barang milik daerah adalah dengan melakukan pengembangan dan pemeliharaan aplikasi sistem informasi manajamen pengelolaan barang milik daerah.
Pengembangan sistem ini dilakukan sebagai upaya untuk mengantisipasi dan menjawab setiap perubahan kebijakan dalam hal penatausahaan keuangan dan aset daerah. Berdasarkan Peraturan Pemerintah Republik Indonesia Nomor 71 Tahun 2010 tentang Standar Akuntansi Pemerintahan, Pemerintah Daerah harus menerapkan laporan keuangan berbasis akrual, yaitu penyajian aset tetap dalam neraca daerah harus mencantumkan nilai akumulasi penyusutan. Untuk mengakomodir kebutuhan data dimaksud maka aplikasi sistem informasi manajemen barang daerah terus dikembangkan.

\section{SIMPULAN}

Berdasarkan hasil penelitian, Implementasi Permendagri Nomor 17 Tahun 2007 tentang Pedoman Teknis Pengelolaan Barang Milik Daerah dalam rangka efisiensi penatausahaan barang milik daerah disimpulkan bahwa implementasi Permendagri Nomor 17 Tahun 2007 tentang Pedoman Teknis Pengelolaan Barang Milik Daerah yang meliputi: 1) Perencanaan Kebutuhan dan Penganggaran, 2) Pengadaan, 3) Penerimaan, Penyimpanan dan Penyaluran, 4) Penggunaan, 5) Penatausahaan, 6) Pemanfaatan, 7) Pengamanan dan Pemeliharaan, 8) Penilaian, 9) Penghapusan, 10) Pemindahtanganan, 11) Pembinaan, Pengawasan dan Pengendalian, 12) Pembiayaan dan 13) Tuntutan Ganti Rugi (TGR) telah dilaksanakan sesuai ketentuan di Kabupaten Ciamis namun belum mencapai derajat kesesuaian terhadap Permendagri Nomor 17 Tahun 2007. Artinya masih terdapat tahapan yang belum dilaksanakan sesuai ketentuan antara lain:

a) Laporan hasil pemeliharaan barang oleh Pengguna Barang kepada Pengelola (Sekda) belum dibuat, 
b) Laporan hasil pengadaan barang oleh Pengguna Barang kepada Pengelola (Sekda) belum dibuat,

c) Surat Perintah Pengeluaran Barang (SPPB) sebagai dasar penyaluran barang oleh pengurus barang belum dilaksanakan, dan

d) Dalam hal pemindahtanganan, laporan hasil penjualan, tukar menukar dan penyertaan modal yang harus disampaikan kepada Menteri Dalam Negeri belum dilaksanakan.

Efisiensi Penatausahaan Barang Milik Daerah dari segi Keandalan, Sistem dan prosedur, Fleksibilitas serta Hasil yang dicapai telah mampu mewujudkan hasil yang baik dalam mengimplementasikan Permendagri Nomor 17 tahun 2007 tentang Pedoman Teknis Pengelolaan Barang Milik Daerah di Kabupaten Ciamis. Dalam rangka meningkatkan efisiensi penatausahaan barang milik daerah, telah dilakukan upaya-upaya sebagai berikut:

a) Kegiatan peningkatan kompetensi sumber daya aparatur pengelola barang milik daerah melalui bimbingan teknis pengelolaan barang daerah bagi para pengurus barang.

b) Penyediaan sarana dan prasarana kerja bagi pengelolaan aset daerah.

c) Pengembangan dan peningkatan aplikasi sistem informasi manajemen barang daerah.

d) Pelaksanaan rekonsiliasi data aset tetap pada setiap awal bulan secara konsisten dan terus menerus.

\section{DAFTAR PUSTAKA}

Arikunto, Suharsimi. 2010. Prosedur Penelitian Suatu Pendekatan Praktik. Jakarta : Rineka Cipta.

Dertouzas, M.L., Lester, R.K., dan Solow, R.M., 2009. Made In America: Regaining the Productive Edge. Cambridge, MA: Harper Perennial.
Hasibuan, M. 2012. Manajemen Sumber Daya Manusia, Edisi Revisi. Jakarta: Bumi Aksara.

John, Soperihanto, 2011. Penilaian Kinerja dan Pengembangan karyawan. Edisi-1 Cetakan-5. BPFE, Jakarta.

Marihot, Tua Efendi. 2009. Manajemen Sumber Daya Manusia : Pengadaan, Pengembangan, Pengkompensasian, dan Peningkatan Produktivitas Pegawai. Jakarta : Grasindo

Megginson, D., Joy-Mattews, J., dan Banfield, P., 2009. Human Resource Development. London: Kogan-Page Limited.

McShane, Steven L., Von Glinow, dan Mary Ann. 2010. Organizational Behavior. USA: McGraw Hill-International

M, Manullang, 2010. Manajemen Personalia Edisi 3. Edisi I, Yoyakarta : BPEE

Nawawi, Hadari. H 2007. Metode Penelitian Bidang Sosial. Pontianak: Gadjah Mada University Press.

Newstrom, K Davis JW. 2011. Perilaku dalam Organisasi. Jilid 1. Terjemahan. Jakarta: Penerbit Erlangga.

Nitisemito, A. S, 2006. Manajemen Personalia. Edisi ke 4. Jakarta: Ghalia

Notoatmojo. 2011. Kesehatan Masyarakat : Ilmu dan Seni. Jakarta : Rineka Cipta

Rahardjo, M. Dawam, 2011. Etika Ekonomi dan Manajemen, Yogyakarta: PT. Tiara Wacana Yogya

Rasyid, H, 1994, Teknik Penarikan Sampel dan Penyusunan Skala, Program Pascasarjana Universitas Padjajaran, Bandung.

Sastrohadiwiryo, B. Siswanto. 2010. Manajemen Tenaga Kerja Indonesia. Bandung: PT Bumi Aksara.

Schermerhorn, Jr., John R., James G. Hunt, Singarimbun, dan Effendi, 2003. Metode Penelitian Survey, Cetakan Kedua, Penerbit Jakarta : PT. Pustaka LP3ES Indonesia.

Sugiyono. 2014. Metode Penelitian Pendidikan Pendekatan Kuantitatif Kualitatif, dan $R$ \& D. Bandung : Alfabeta.

Permendagri Nomor 17 Tahun 2007 tentang Pedoman Teknis Pengelolaan Barang Milik Daerah 